\title{
RELATIONSHIP AMONG POLITICAL INSTABILITY, STOCK MARKET RETURNS AND STOCK MARKET VOLATILITY
}

\author{
IRSHAD Hira \\ School of Economic Finance and Baking, University Utara, Malaysia
}

\begin{abstract}
:
This study investigated the relationship of political instability with the stock prices. Results of the study indicated the negative relationship of stock prices with political instability. Moreover, results of suggested that instable political system ultimately leads decline in stock prices. Inflation has shown negative relationship with stock prices whereas, industrial production and Exports have positive relationship with stock prices.
\end{abstract}

Key words: political instability, stock market returns, stock market instability, corporate investing behaviour

\section{Introduction}

This study examines the effects of political uncertainty on corporate investing behaviours by analysing the change in stock prices as a result of uncertainty in political system. It is most commonly thought that if political system in any country is uncertain then investors will remain under a fear of losing their wealth. However, is it really the case with every country? Or is it possible that investors do earn better returns in weak political systems by having easy access to the law making authorities? This study has focused the issue of stock returns in an uncertain political environment. It would make some contribution in already going debate on this topic by providing empirical evidence on this relationship in a country where political instability is the major macroeconomic risk.

The reason that it will increase the clarity about the relationship between political uncertainty and stock prices is that Pakistan is a country having half of her age led by military governments and remaining by democratic governments. There exists problems with both type of regimes, further dictatorship can be classified in to two more classes, kleptrocatic dictatorship and technocratic dictatorship, kleptrotic 
dictatorship is the worst form of regime for economy because it is a government for one itself and to increase personal wealth, democracy also has to face the problem because it is a type of government formed by people, so according to majority of votes different pressure groups try to put undue influence which leads to corruption and problems in running of government, but democracy is considered better than kleptrocatic dictatorship.

Technocracy is top in ranking according to economy of a country; it is that type of government in which related institutions are being run by best related people. Historical patterns show that technocratic dictatorship regime stocks markets always outperformed the stock markets of democratic regimes or kleptrocatic dictatorship. History of Pakistan has showed that country has been growing more rapidly whenever it has been ruled by the Military-led governments. Pakistan has shown better performance in terms of its equity market, Education, Basic Infrastructure and other parameters which ultimately lead her towards a better country during Military-led governments. For instance, Khan (2012) stated that many of the economic indicators were healthier during military led governments as compared to civilian governments. This study investigated the impact of political instability on equity returns in Pakistan.

\subsection{Relationship between stock market and political stability}

Literature provides evidence on relationship between political instability and stock prices. Alesina, et al. (1992) found that stability of the government would tend to increase the growth of economy. Barro and Lee (1994) concluded that political instability and economic growth are negatively related. Likewise, Beaulieu et. al. (2005) found that stock return volatility increases as level of firm's exposure towards political risk increases.

Political instability sometimes may tend to support some industries and hampers the returns for other industries. Any political government come into power after getting votes from the public and government policies are designed to address the policies that cater their electoral base Hibbs (1977). This perspective may help to understand the volatility in stock returns in response to the change in government. Investor perceives desired policies of the prospective and fresh government which may affect their portfolios. Some evidence exist which support the notion that party orientation has a significant role in determination of equity prices (Bernhard \& Leblang, 2006; Foerster \& Schmitz, 1997; Knight, 2006; Leblang \& Mukherjee, 2005; Snowberg et.al. 2007; Wolfers \& Zitzewitz, 2009).

Political Parties do have difference in their stance towards the legislation for labour and upper class voters. Literature shows that right-wing parties are mostly focused towards upper class voters, whereas left-wing parties focus on lower class voters/working class. Labour intensive industries may have negative effect on their share prices if, right wing party comes into power (Alesina et. al 1993; Alt \& Chrystal 1983; Botero et al. 2004). This fact clarifies the link between orientation of ruling party and equity market investor perception towards their future wealth. 
There are few studies where evidence was found that autocratic governments tends to create greater volatility in economic growth in long term and on the other side stable situation in long-term economic performance (Przeworski et al. 2000; Almeida \& Ferriera 2002). On contrary, there are few studies stating that policies are stable in short run during autocratic regimes (Kenyon \& Naoi, 2010). Similarly, Other type of political risks are also associated with the economic situation of the country and these factors also explain the behaviour of stock prices as government stability, socioeconomic stability, religious tensions, etc.

Change of government is basically the transfer of control from one group of people to the other where economic development is the common goal. Government may not be in power after next election if fails to deliver for what it was elected by the people. Threat of not coming into power in next term may cause pressure on governments to nurture the economy. However, the objective of governments to nurture the economy faints after getting into the power because new government either suspend the projects initiated by the previous government or re-launch with new identities in the purpose of getting the credit for those projects. The objective of government to show the progress to people sometimes dominates the real objective of economic growth and sometimes former may also substitutes the later. Whatever the situation is; either it is suspension of previous project or project has been re-launched bring additional cost which is ultimately borne by the public in the form of taxes (Asteriou \& Price, 2001).

Government servants are unceremoniously transferred and substituted with those loyal to the new government. These changes in civil servants enable the government to impose the policies without any resistance. Public interests are given up in exchange of interests of a political party. The unceremonious transfer orders by the government encourage the government officials to practice the same policies within their span of control. This is the way how unofficial government policy of preferring loyalty over honesty and rules becomes the unofficial policy of government institutions. The unstable political environment weakens the regulatory bodies and these effects are transmitted to the equity market.

\subsection{Market Volatility}

In simple words volatility refers to the statistical measure of dispersion of returns for a given security or market index, it is also the indicator of risk, higher the volatility means higher the risk in market, in simplest way volatility is measure through standard deviation and variances of returns. This study has used Auto Regressive Conditional Heteroscedasticity $(\mathrm{ARCH})$ to quantify the volatility of market. The rationale behind using ARCH model is discussed in detail under data \& methodology section. Volatility shows the up and down movement of market, so any movement up and down from the expectation is the volatility and volatility never remains same but keep on changing so we go through high and low volatility periods. 
Do asset prices changes over time? we buy an asset with the expectation of future payments by that asset, for asset pricing we forecast possible inflows present in the asset, and forecast of inflows depends upon the best possible information which we have today but the information does not remain same forever as we get new information we make new forecast of inflows which may change the prices of assets and causes volatility, it has been observed that new information and happenings react more quickly in the bearish markets, so we use to say that volatility is higher when there is drop in the market. Volatility also change with major happenings in the market and country and the major problem of country like Pakistan is dreadful political situations so I am linking the volatility with the political instability, for the support of my work.

\subsection{Relationship between stock market and economy}

Stock markets are best indicator of economy and play an important role in the economy of country by pushing up the commerce and industry. That is why, investors, industries, governments, and even central banks keep close eye on stock markets. Economy of a country depends on well performing industries and corporate sector. The progress of these both is associated with profitability and easy availability of capital. The stock market is the place which reflects not only profitability, trade success but also a best provider of capital for listed companies. The basic source to raise fund is stock market, if somebody wants to put his funds to some security, the stock market is the best place for him to see. Equity Markets do provide the option to convert your savings into investments and to convert your investments again into liquid form.

Equity market provides an option to put your saving into investments. This is the primary function of the stock exchange. Equity market plays an important role in supporting the growth of industry and commerce in a country. Increase in the volume and value of equity market index is a sign for developing industrial sector. As secondary function equity market provides platform for buyers and sellers to buy and sold different securities, and forms the trade volume of a country. Similarly, it provides protection to the investors through the regulations and market protection. High volume of trade is a good indicator for an economy of a country.

Stocks markets may lessen the cost of savings mobilization, facilitate the investor to invest into the most fruitful stocks, so well performing stock market is the indicator of well performing economy (Greenwood \& Smith, 1996). According to Mohtadi and agarwal (1998) equity market is the reflection of the overall economy. They found that there is positive relationship between stock markets and economy, means conditions of stock market and conditions of economy of a country moves in same direction, well performing stock market is indicator of well performing economy and poorly performing stock markets indicating the poor condition of country, so wellfunctioning of the equity markets also reflects the overall prosperity and growth of the economy. 


\subsection{Significance of Study}

This study aims to explore the relationship between political instability and stock market performance and market volatility. This study will elaborate the collective effect of events like strike, assignations, riots, demonstrations, government change, and government longevity on stock market returns. This study is of great significance for portfolio managers and investors while making their investment choices. Similarly, the findings of this study may help regulatory authorities and government. The nature of relationship between political instability and stock market provides significant information to make investment choices. Long run existence of the shocks in stock prices due to political instability and short run disequilibrium in stock prices generates signals for investors. Stock market in this study is proxy for the economy of country. Similar studies have been conducted before and have given varying results. Some of these studies has used GDP growth and other used other variable like industrial production, foreign direct investment as indicators of economic performance. This study will consider the equity market as indicator of economic performance because behaviours of investor community are truly reflected in equity market prices. Another aspect which makes my study special is that it will also explain the volatility in market as a response to different political events.

\section{Literature review}

Previous Literature on the Political Instability and macroeconomic variables has provided considerable evidences supporting the relationship between political instability and economic growth. However, the nature of the relationship according to these evidences is mixed regarding the direction of the causality among macroeconomic variables and political Instability. These points direct the research towards the notion that instability in the government will cut the progress of the ongoing long term projects and will create disturbances for the economy to progress (Asteriou \& Price, 2001)

Another point that Literature provide is the ways that are open to the business community when economy is politically not stable. In such situation business community may found the ways to get the subsidization from the government because of the pressure it already has been facing from the opposition. This pressure sometimes paves the way towards the policies which support a particular group which may belong to the equity market. Whatever else is happening with the economy, sometimes a particular sector does get benefits when governments are not powerful (Asteriou \& Price, 2001). However, a number of studies which had been conducted in the past regarding political instability are discussed in the next section of Literature Review. A list of most significant contributions in the literature of Political Instability is discussed. 
Niederhoffer (1971) examined the impact of world events on stock market. His study investigated the relationship of world events with the S\&P 500 index. World events were taken from the leading News Paper in US the New York Time's. Headlines were taken from the New York Time's and were used as events. Results of this study reported that world events affected the fluctuations of the S\&P 500 Index. Results were that world events do bring larger change in returns than the normal returns.

Bittlingmayer (1992) find out the causal relationship between stock prices and political instability in Germany. For this purpose, his study used monthly data of German Stock Exchange and found that the volatility in stock market higher when combination of different political events occurs. Moreover, he argues that in the opening year of the system in Germany the volatility was higher. His Study also confirmed that revolution, war race, overthrowing of governments, violent uprising against authority and strikes directly responsible for higher volatility in stock returns. His study also found that equity market volatility has negative impacts on industrial production. He did not found any exact causal relationship in its place. His study reported that political instability has negatively affected the industrial production and also increases stock market volatility.

Alesina, et al. (1992) explores the connections between political instability and economic growth. They took sample of one hundred and thirteen countries for the period of 1950-82. This study used the simultaneous equations model and tried to measure growth of the economy and political insecurity. This study also used the Amemiya's Generalized Least Square technique (AGLS). It was found that when chances for government to survive are lower, it would also decrease the rate of growth for the economy. Similarly, if there would be stability of the Government, there would be higher rate of the growth in the economy.

Barro and Lee (1994) examine rate of growth in the world taking data from different countries. Their study took sample from one hundred and sixteen countries. Data was collected for these countries from the year 1965 to 1985. Their study estimated the factors that may determine the growth of country. Their study investigated the relationship between growth and politics situation. This study measured the political instability by calculating number of revolutions that were happened during the sample period. This study concluded that political situation and growth of any country are negatively related.

Feng (1997) investigated the relationship among three variables which were democracy, political instability and economic growth. Simultaneous Equation was used by applying three stage least square on ninety-six countries data from 1960 to 1980 . The results indicated that whenever there was a change in the government or in the constitution, it has opposite effect on the growth of country. On the other hand, growth was making a change in regime and change in government.

Klibanoff et. al. (1998) examined the effects of different big news events on close ended mutual funds. Their study analysed the effects of big news events on investing behaviour of traders. Results of their study indicated that average returns and standard deviation of these funds changes sharply in those days when media 
announces major news events. Furthermore, their results showed that elasticity of funds in relation to their net asset values.

Guillaumont et. Al. (1999) conducted this study to explore the effects of instabilities on growth rate in Africa from 1970 to 1990. This study includes the sample of African and non-African countries and used cross section statistical estimations. One of these instabilities was political instability and role of political instability in low growth rate was also identified. Results clarified that political instability has hampered the growth rate. Political Instability has lowered gross domestic product for these countries.

Brempong and Traynor (1999) investigated the relationship between political instability and economic growth. They took the sample of 39 African Sub-Saharan Countries. Data was analysed using Simultaneous Equations Model and Panel Data Estimation. Data were taken from 1975 to 1988. Results of this study reported that political instability reduces the economic growth of the country and political stability increases the economic growth of these countries.

Bussie and Mulder (2000) investigated the effect of political uncertainty on economic vulnerability. Data was collected from 1994 to 1997 in context of political instability. Results showed that political instability have great impact in low reserve countries on economic vulnerability. Results of the study reported that countries became vulnerable during the phase of elections.

Asteriou and Price (2001) analysed that whether political instability does have any relationship with economic growth in the United Kingdom. They used the data for political instability and economic growth from 1961-1997. Data was analysed by using GARCH, GARCH-M and ordinary least square regression models. For political instability they made an index by using Principal Component Analysis. Results of this study were that political instability hampers the growth rate in UK and similarly political stability increases the growth rate.

Mei and Guo (2002) investigated the effects on financial crises as a result of political unrest. Panel data of emerging markets of twenty-two countries was used for analysis. It was found that out of total nine crises happened in these economies were during the time period of elections and transfer of power from one government to the other. Data was analysed using Probit regression and switching regression analysis. Results of their study concluded that there exists relationship between elections and political instability. It was also reported that market volatility was high during these time periods. Authors hold an opinion that institutional investors in the emerging economies hesitate to invest in the market during the phase of frequent changes in the government.

Camposw and Nugent (2003) this study examines the relationship between political uncertainty and level of investments in the long run. Political instability was measured by Social and Political Instability (SPI) index. SPI was consisted of three components; revolutions, political assassinations, and successful coups d'état. Data were taken from Year 1960 to 1995. This data was representing almost 94 countries from developed world. This relationship was examined by Anderson-Hsiao-Arellano 
instrumental variable estimations using Granger causality framework. Results provided the causality patterns running between political uncertainty and level of investments. These results showed the positive relationship between Investment and Social and Political Instability Index. However, results showed negative relationship in case of simultaneous equation between investment rate and SPI.

Hussain and Qasim (2007) investigated the effect of social unrest on the economic situation by taking the stock market as proxy for the economic development. Result of this study supported the hypothesis that stock returns tend to move in response to different political events. Data was used from 1960 to 2000 . It was reported in the results that stock market was at normal stage during 1980s but gained energy after the liberalization in 1990s.

Omar Masood (2008) investigated the effects of political risk on the equity market of Pakistan since 1947. This study collected the data by using questionnaires. After collection of data, Bayesian hierarchical modelling and Markov Chain Monte Carlo (MCMC) technique was used to get the results. Results of this study suggested that political risk do create risk premium and approximately $7.5 \%$ to $12 \%$ risk premium is required by investors. They further reported that any event of political nature does have high probability of happening without any trend.

Valkanovn (2008) examined that under different presidential regimes growth of industries varied with respect to the nature of the industry. Moreover, this study reported that during Republican Government tobacco industry, telecommunication industry and chemical industry performed well. In democratic government time periods real estate sector, construction industry and services industry performed better. The studies related these differences in industry performance with different rational. First they referred the difference to the political variables working as proxy for the businesscycle variables. Secondly, this difference was referred towards the election. Third reason for this difference as reported by the study was referred to the difference risk of the equity market during different presidential regimes. This study used the data for the firms from the year 1963 to 1998 . This study reported different results as compared to the previous studies. In addition, this study reported that there was no evidence of difference in average returns before and after the election.

Malik et al. (2009) examined the impacts of political instability on volume and returns of the equity market. For this purpose, they took data from 18th February 2008 to 18th February 2009. Data was divided into pre resignation period of General Musharraf and post resignation period of Musharraf. Data was analysed using by using co-integration technique. It was found that positive relationship prevails between volume and returns. It was also observed that the relationship was highly significant in post resignation period. The correlation between trading volume and returns which was 0.490 in pre resignation period went up to 0.795 in the post resignation period. This shock of political event remained effective till end of 2008. The Stock Market once went up on 18th august when Musharraf gave resign and after 2 to 3 days it started decline. The reason for this decline might be the political situation which was perceived by the investor at that time. Investors bringing their investments to a halt gave a message of 
uncertainty to the market. Therefore, this study proved that positive relationship prevails between volume and returns where political events also play a very positive role in explanation of stock market behaviours.

Khan and Ahmed (2009) examined the relationship between political events and equity market of Pakistan by taking KSE 100 index as proxy for the equity market. This study addressed the relationship of stock returns and trading volume in the presence of different political events in Pakistan. Different political events do affect the stock market by creating uncertainty for the investors in terms of operational risk. This operational risk reduces the volume of trade in the market and induces the investors to pull up their investments from the market. This relationship does affect the trading volume and stock prices in Pakistan. The study hypothesized that political events affect stock returns and trading volume as well. Results of the study provided evidence that political events significantly affect returns and volume. Furthermore, results indicated that changes in volume is transmitted to the stock returns.

Clark, Masood and Tunaru (2009) have examined that how political instability has affected the equity market of Pakistan. This study analyse that levels of political risk linked with Pakistan equity market and answered if this relationship has remained in the past and what it is likely to be in the future. The purpose of this study was to check that whether Political events do affect stock market returns. Political risk, rare events were the variables studied in this paper. The data was analysed using Bayesian/MCMC Methodology and Markov Chain Monte Carlo (MCMC) techniques. These techniques were appropriate to use when the issue is regarding political instability due to the rare events and because data is sparse. This study concluded that the chances of occurrence of any event in any particular year are found to be high. This study found that there exists no time trend in terms of the arrival rate, therefore, signifying that happening of these events is not increasing. On the other side, happening of these events is also not declining during this period.

Qureshi et al (2010) explored the impact of instability in political situation on growth of country by using stock market returns as the proxy for economy. For political instability authors constructed the political instability index for seven variables. This study took data from 1971 to 2010 and find out that although average economic growth throughout past is good at average of $5 \%$ approximately. Even than there is very clear impact of political instability on economic development, situation of political instability badly hit some areas of economy. The volatility in stock returns and economic development was high during the period of high political instability.

Durnev (2010) examined the impact of political uncertainty on investment sensitivity and share price sensitivity. This study explored that how elections effect investment sensitivity and share prices and found that share prices are $60 \%$ more sensitive than investment during the election years as compared to non-election time period. According to this study managers of firms normally consideration for changes in equity prices during election is very minute. This study also suggested that because of election uncertainty capital allocation become more inefficient, and normally company's investment is very less responsive to stock prices. If this phenomenon happens 
companies on average will face $6 \%$ lower growth in sales after two years of elections. Therefore, concluding the paper, political uncertainty plays a very negative role in capital allocation and movements of stock prices.

Liu (2010) explored how negative impact of political uncertainty on corporate investments can be removed by the help of well-functioning legal institutions which protect institutional investors. For this purpose, data was collected samples for 40 countries from the year 1981 to 2009 . The study concluded that during the election times companies do reduces their investments and increases their investments after the election. It was discussed that companies observe the economic conditions after the election and make investment decision depending on the economic position of the country. It was found that there exists positive relationship between the protection to the institutional investors and their investments. It was contended that legal protection provided to the institutional investors do relate with the level of corporate investments during election years. It was reported that legal protection provided to the institutional investor will waive off the negative effects of political instability on the corporate investments. At the end it was reported that investments of institutional investors, net profits and cash flows and economic development are positively related.

Hussain et.al (2010) made a review of Pakistani equity market for past 50 years. According to their study, market at different time intervals have major disturbance because of different political wrong happenings. Equity market gain momentum in 1960s but after war of 1965 and separation of Bangladesh in 1971 along with nationalization policies of government Equity Market was faced with hard situation. From 1970 to 1980 , when government started high reliance on private sector, the stock market regained its momentum. In 1991stock market was made open to foreign investors as a result of liberalization of stock markets in the whole world. It showed that the equity market was at good pace at that time and was improved considerably. But afterwards market did not stabilize its progress because of many factors like inflation, political instability, widening budget deficits and unemployment rates. Furthermore, it was concluded that after specific time period market behave differently and the major reason of this changed behaviour is problems in political systems.

Khan and Saqib (2010) examined the effect of political instability on inflation in Pakistan. This study used the data from 1951 to 2007. Data was analysed the by applying the technique of generalized method of moments. Interactive dummies analysis confirmed that political instability in the country is the major cause of high rate of inflation in the country. If the governments are really interested in the minimum rate of inflation in the country; they have to contribute in terms of the stability of the political situation.

Tang and Abosedran (2013) investigated the impact of sectors like tourism, consumption of energy and political instability on growth of the economy. Data was used from the year 2001 to 2009. Panel data of twenty-four countries was collected. These twenty-four countries were from Middle East and North African Countries. Data was analysed using dynamic GMM (Generalized Method of Moments) and static panel data approach. Results reported that tourism industry and consumption of energy do

\section{- 79 -}


have positive and significant effects on the growth of the economy. Furthermore, their results contended that political instability hampers the growth of the economy.

Gul et al. (2013) proved that political instability does have considerable effect on the stock prices. This study used event study methodology for testing this relationship. His study found that 2008 financial crises time was the time of hardships and difficulties for the equity market investors. Author further made an opinion that during 2007-10 time, the equity market faced difficulties because of happenings of events which has reduced foreign and domestic investment in the market. Stock market did not perform better in that time and besides these issues other factors like terrorist attacks, 9/11 terrorist attack in USA and its after effects to the rest of the world, bombings, and assassination of major political leaders like the assassination of Benazir Bhutto, Nawab Akbar Bugti. Political instability was also increased because of judiciary and General Mushraf clashes, militant attacks in tribal areas and also in Malakand division, drones attack by the United States and many other issues made the situation of Pakistani equity market even worse. Karachi stock exchange 100 index was launched first time in 1997 with a base value of 1000 and it rose to the 1770 points in 2001. In 2005 Karachi stock market 100 Index reached at the level of 9989 points. In the year 2007 it reached to 12285 points and in December of the same year points soared to 14814 points. But on December 26, 2007 assassination of Benazir Bhutto the decline of the stock market 100 Index was not recovered till the end of 2008 . However, during this period index gained a high point of 15500 in April, 2008 but till the year of 2008 it was touching its floor.

Chen et al. (2013) examined international instability and its effect on internal stock prices. This study considered growth rate of global military expenditure to GDP ratio as a proxy of international instability. This study included market prices from equity markets of 49 countries. This study ascertained that international political instability is a considerable pricing component for the equity market returns. The reason for international political instability as a pricing component due to the risk involved by emerging equity markets is the difference of average annual returns in developed and emerging equity markets. It could be observed from the fact that average annual return for developing equity markets is $19.96 \%$ from 1988 to 2009 . On the other side, average annual return of the equity market for developed markets is only $9.23 \%$. Due to the fact that emerging equity markets are more volatile towards international political situation the annual risk premia also differ considerably in these two segments. Annual Risk Premium earned by emerging equity markets is $15 \%$ and $5 \%$ for developed equity markets. This study also addressed that sometimes expectations impact the returns largely than the real happenings of the events. Authors hold an opinion that Arms race between United States of America and the Russia made investors more responsive to the relevant news than the actual wars around the globe. 


\section{$\underline{\text { Hypothesis }}$}

$\mathbf{H}_{1}$ : Political Instability has short run relationship with stock market returns and volatility.

$\mathbf{H}_{2}$ : Political Instability has long run relationship with stock market returns and volatility.

\section{Research methodology}

\subsection{Data Collection and}

The data for political instability is accessed from the leading newspapers and the book "Pakistan 58 years" (Razi \& Shakir, 2005). Data for the stock market index is extracted from the yahoo finance from the year 1998 to 2012. There are number of techniques which may help to examine this relationship. For analysing long run relationship between political instability and stock market index ARDL Co-integration have been used. ARDL approach was proposed by Pearson and Shin (1999). Ouattara (2004) found that if data is found integrated at I(0) or I(1) then ARDL Co-integration approach is applied. He reported that in bounds test there is assumption that data is $\mathrm{I}(0)$ or I(1), therefore, in presence of $\mathrm{I}(2)$ variables the computed $\mathrm{F}$ Statistic provided by Pearson et. al. (2001) becomes invalid.

Co-integration assumes that data must be stationary and data should be integrated of same order. This study adopted ARDL Co-integration because of integration of the series at different orders. Unit root test was used for checking stationarity of data. For the purpose of short run relationship Error Correction Model was used. Market Volatility is analysed using ARCH and GARCH methodology.

\subsection{Variables Description}

\subsubsection{Construction of political Instability index}

Political instability will be measured by the factors like demonstrations, assassinations, strikes, longevity of governments, riots etc. An index of political instability was constructed using Principal Component Analysis.

\subsubsection{Summary of political instability index}

This study used eight factors to construct the political instability index. First factor is general strike measured as when employees of any company or organization goes against government strategy and they are more than thousand. Second factor is Demonstrations measured as when more than one hundred people go against government policies but do not become violent and their gathering remains peaceful. Third factor is riots measured as when more than one hundred people goes against government policies but do becomes aggressive and use physical force. Fourth factor is Assassinations measured as murder of any leaders who belongs to any political party. Fifth factor is Government's longevity measured as Years a government rule. Seventh factor is governments change measured as any event of change in 
government. Eighth and last type of factor is regime type measured as Military led government or democracy.

\subsubsection{How to Calculate Stock Returns}

Stock prices data extracted from www.yahoo.finance.com is used to calculate the equity market returns. Karachi Stock Market 100 index served as the proxy for stock returns. Stock Returns were calculated using the following model.

$\mathrm{R}=\ln \left(\mathrm{P}_{\mathrm{t}} / \mathrm{P}_{\mathrm{t}-1}\right)$

Whereas $R$ is stock return., Ln refers to natural log, $P_{t}$ refers to index of current day and $\mathrm{P}_{\mathrm{t}-1}$ refers to index of previous day

\subsubsection{Control Variables}

The following control variables were also included in the study in order to explore the relationship of stock market with political instability in the presence of macroeconomic variables which directly affects the stock market.

\section{Inflation}

Inflation is used as control variable in the study. Inflation consumer price index (CPI) is taken as proxy for the inflation in the Pakistan. Consumer price index calculates the change in the price of goods and services during a period of time. Increase in inflation raises the discount rate to calculate the expected value of the securities. An increase in inflation increases the discount rate to value the securities and it will decrease the prices of the securities. Expected relationship between stock prices and inflation is negative.

\section{Industrial Production}

Industrial production has been used as proxy for measuring the growth rate in the real sector of the economy. Industrial production affects the cash flows of the corporate sector and these cash flows leads the stock prices to increase. Due to industrial production cash flows of the firm increases. Increase in cash flows of corporation rose up the discounted value of the cash flows and market price of share goes up. The expected relationship between stock price and industrial production is positive.

\section{Exchange Rate}

Exchange rate is used as control variable in this study and expected relationship of exchange rate with stock price was that any decline in home currency will negatively related to equity prices. This study took month end US\$/Rs. Exchange rate as proxy for exchange rates. 


\section{Exports}

Exports represent good sold outside the country measured in local currency. Exports do increases the expected cash flows for the corporations. Increase in cash flows will raise the discounted value of securities and expected relationship between exports and stock prices is positive.

\subsubsection{Market Volatility}

Most of the investors might consider equity market as risky place therefore, consider market volatility in portfolio analysis. The daily, quarterly and annual movements of return can be theatrical. But this volatility is also cause for market returns. One way to simply define volatility is, it is deviation of returns, if returns are closely bunched we can say that there is less volatility in returns and if there is high spread in returns means dispersion is high. Auto regressive conditional heteroscedasticity is best to measure variations in error term so this technique is useful to calculate volatility.

\section{Data analysis}

Table 1 represents the principal component analysis results for construction of political instability index. Data for the construction of political instability index was used from the year 1998 to 2012 . Political instability index is constructed using different factors which may create unstable political environment. List of these factors is discussed above in chapter 3 . The factors which are used to construct the political instability index are General Strikes, Demonstrations, Riots, Assassinations, Government's longevity, Governments change and Regime Type. Political Instability index is constructed based on the Eigen Values. The components which showed Eigen value of more than 1 are included in the index. First three factors explain the major variance in the index and those three components therefore, are selected and included in the index. These components are further explored with rotated component matrix. The results were further explored with the help of rotated component matrix.

Index Transformation Formula: Index Transformation Formula:

Transformed Index $=\mathrm{a}+(\mathrm{bx})$

Where, $a=(X 2-b X 1)$ and $b=(S D 2 / S D 1)$

Summary of political instability index

The factors used to address the issue of political instability are directly related to the situation in Pakistan. Principal Component Analysis is used to construct the index. PC1 is transformed using the formula used in the previous studies. A concise review of PC 1 is presented in Table 1 and 2.

$\mathrm{PI}=.880 \mathrm{Z1}+.254 Z 2+.883 Z 3+.091 Z 4+.054 \mathrm{Z} 5-.257+.220 Z 7$ 
Where $\mathbf{Z 1}$ to $\mathbf{Z 7}$ are explained below with detail. The index calculated using Principal Component Analysis is then standardized in order to make them unbiased. The political instability index is then transformed using mean 100 and using standard deviation 10 for achieving better output.

\begin{tabular}{cc}
\hline Z1 & Strikes \\
Z2 & Assassinations \\
Z3 & Riots \\
Z4 & Demonstrations \\
Z5 & Government Longevity \\
Z6 & Government Change \\
Z7/ & Regime Type \\
\hline
\end{tabular}

Political instability index is constructed using SPSS 16.0 software. For making the index, this study used Principal Component Analysis and used the first component following previous studies. Previous Literature on construction of political instability index supports this method such as Alesina and perotti (1996), Campos and Nugent (1999), Qureshi et al. (2010) and Ali et al. (2013). These studies took first component of the Principal Component Analysis in the construction of Political Instability Index.

\subsection{Construction of Political Instability Index (Principal Component Analysis)}

Table 1: Principal Component Analysis (Total Variance Explained)

\begin{tabular}{|c|c|c|c|c|c|c|c|c|c|}
\hline \multirow[t]{2}{*}{ Component } & \multicolumn{3}{|c|}{ Initial Eigenvalues } & \multicolumn{3}{|c|}{$\begin{array}{c}\text { Extraction Sums of Squared } \\
\text { Loadings }\end{array}$} & \multicolumn{3}{|c|}{$\begin{array}{c}\text { Rotation Sums of Squared } \\
\text { Loadings }\end{array}$} \\
\hline & Total & $\begin{array}{c}\% \text { of } \\
\text { Variance }\end{array}$ & $\begin{array}{c}\text { Cumulative } \\
\%\end{array}$ & Total & $\begin{array}{c}\% \text { of } \\
\text { Variance }\end{array}$ & $\begin{array}{c}\text { Cumulative } \\
\%\end{array}$ & Total & $\begin{array}{c}\% \text { of } \\
\text { Variance }\end{array}$ & $\begin{array}{c}\text { Cumulative } \\
\%\end{array}$ \\
\hline 1 & 1.911 & 27.298 & 27.298 & 1.911 & 27.298 & 27.298 & 1.745 & 24.929 & 24.929 \\
\hline 2 & 1.599 & 22.841 & 50.139 & 1.599 & 22.841 & 50.139 & 1.727 & 24.670 & 49.599 \\
\hline 3 & 1.219 & 17.418 & 67.556 & 1.219 & 17.418 & 67.556 & 1.257 & 17.957 & 67.556 \\
\hline 4 & .938 & 13.406 & 80.962 & & & & & & \\
\hline 5 & .611 & 8.732 & 89.694 & & & & & & \\
\hline 6 & .474 & 6.775 & 96.469 & & & & & & \\
\hline 7 & .247 & 3.531 & 100.000 & & & & & & \\
\hline
\end{tabular}

Extraction Method: Principal Component Analysis. 
Table 2: Rotated Component Matrix

\begin{tabular}{lccr}
\hline & \multicolumn{3}{c}{ Component } \\
\cline { 2 - 4 } & \multicolumn{1}{c}{1} & 2 & 3 \\
\hline STRIKES & .880 & .098 & .013 \\
ASSASINATIONS & .254 & .269 & .396 \\
RIOTS & .883 & .009 & .065 \\
DEMONSTRATIONS & .091 &. .317 & .851 \\
GOVT LONGEVITY & .054 & -.872 & -.015 \\
GOVT CHANGE & -.257 & .448 & .609 \\
REGIME TYPE & .220 & .763 & .002 \\
\hline
\end{tabular}

Extraction Method: Principal Component Analysis. Rotation Method: Varimax with Kaiser Normalization. a. Rotation converged in 4 iterations.

\subsection{Diagnostic Tests and Data Descriptive Statistics}

Table 3: Descriptive Statistics

\begin{tabular}{lcccccr}
\hline & KSE & PI & CPI & IP & ER & EXPORT \\
\hline Mean & 0.013139 & 0.006981 & 0.001796 & 0.003545 & 0.004431 & 0.004496 \\
Median & 0.019802 & 0.014298 & -0.009057 & 0.004515 & 0.001480 & 0.008192 \\
Maximum & 0.241114 & 1.149323 & 0.476291 & 0.151107 & 0.075241 & 0.230347 \\
Minimum & -0.448796 & -1.816134 & -0.466175 & -0.157629 & -0.029114 & -0.277107 \\
Std. Dev. & 0.095473 & 0.237131 & 0.142576 & 0.050577 & 0.012979 & 0.077842 \\
Skewness & -1.205613 & -2.539380 & 0.019969 & -0.358159 & 2.515580 & -0.468239 \\
Kurtosis & 7.558975 & 28.50002 & 4.009845 & 4.791546 & 12.02582 & 4.373174 \\
Jarque-Bera & 198.3788 & 5042.169 & 7.617801 & 27.76550 & 796.3860 & 20.60439 \\
Probability & 0.000000 & 0.000000 & 0.022173 & 0.000001 & 0.000000 & 0.000034 \\
Sum & 2.351917 & 1.249681 & 0.321453 & 0.634498 & 0.793174 & 0.804733 \\
Sum Sq. Dev. & 1.622470 & 10.00910 & 3.618374 & 0.455324 & 0.029984 & 1.078566 \\
Observations & 179 & 179 & 179 & 179 & 179 & 179 \\
\hline
\end{tabular}

Descriptive Statistics are used to identify the characteristics and the behaviours of the data. Arithmetic Mean tells us about the average returns for the Karachi Stock Market. Standard Deviation tells us about the deviation of the values of series from their average value. Standard Deviation of the Karachi Stock Market will represent the riskiness that exists in the returns of the market. Skewness represents the tendency of the data whether most of the returns are negatively or positively skewed. Average returns of the Karachi Stock Market during 1998 to 2012 were 0.013139 with standard deviation of 0.095473. Average change in Political instability index during 1998 to 2012 was 0.006981 with standard deviation of 0.237131 ; similarly, average change in inflation during 1998 to 2012 was 0.001796 with standard deviation of 0.142576 . Industrial Production, Exchange Rate and Exports are also examined and their average returns are given in above table which are 0.003545 , 0.004431 and 0.004496 . The values of their standard deviation are respectively $0.050577,0.012979$ and 0.077842 . Descriptive Statistics also showed that most of the 
returns for Karachi Stock Exchange, Industrial Production, Political Instability and Exports are negatively skewed while most of the values are positively skewed for CPI and Export.

Unit Root Test is used to identify the stationarity of the data. The data is supposed to become stationary when its values are independent of its lagged values. When values are not dependent on the lagged values of the same series then series will not show any particular trend and behaviour. Basically a stationary series is that series which is independent of its previous terms or the series where values are random. Unit Root Test is used to identify the level of stationary of all the series included in this study. Two types of tests are employed to check the level of stationary of the series. First is the ADF (Augmented Dickey Fuller Test) and second is PP (Phillip Peron Test). The level of integration of all the series checked through ADF and PP Tests are given in Table 3.

Results show that Karachi Stock Market Index, Political Instability Index, CPI (used as proxy for inflation), Industrial Production, Exchange Rate and Exports were non-stationary at levels as reported by ADF Test and Phillip Peron Test. These series were re-examined using ADF and PP Tests by taking the first differences. The results of ADF and PP Tests after taking first differences showed that except Political Instability Index all the other variables become stationary at first difference. The cointegration requires that all the data should be stationary and that data should be stationary at same level. If data is not found integrated at same level, then cointegration is not appropriate to apply. Results of this study showed that all series were not integrated at same order and it urges the author to apply the ARDL Cointegration which is appropriate to use when series are not integrated at different levels.

Table 4: Unit Root Test

\begin{tabular}{lllll}
\hline & ADF Level & ADF First Diff. & PP Level & PP First Diff. \\
\hline KSE & -0.50718 & -9.05402 & -0.51708 & -12.7019 \\
PI & -0.33932 & -0.10296 & 0.209248 & -1.52744 \\
CPI & -1.62818 & -9.22831 & -1.56962 & -12.6987 \\
IP & -1.27022 & -13.229 & -1.3453 & -16.0107 \\
ER & -0.50225 & -6.76879 & -0.24555 & -8.21694 \\
Export & -1.46011 & -13.7418 & -2.01121 & -23.5742 \\
& & & & \\
\hline $1 \%$ & -3.46721 & -3.46742 & -3.46699 & -3.46721 \\
$5 \%$ & -2.87764 & -2.87773 & -2.87754 & -2.87764 \\
$10 \%$ & -2.57543 & -2.57548 & -2.57538 & -2.57543
\end{tabular}

Table 4 represents the diagnostic tests for the data. This table represents the autocorrelation, Normality and Heteroscedasticity tests for the data. The Chi Square value and the probability values represent that these series were suitable for the estimation of the ARDL (Auto Regressive Distributive Lag) Model. 
Table 5: Diagnostic Tests

\begin{tabular}{|c|c|c|c|}
\hline Property & Test & CHSQ (x2) & Prob. \\
\hline Auto Correlation & LM Test & .0031115 & .956 \\
\hline Functional Form & Ramsey's RESET test & .20576 & .650 \\
\hline Normality & $\begin{array}{l}\text { Test of skewness and } \\
\text { Kurtosis }\end{array}$ & 1.2481 & .536 \\
\hline Heteroscedasticity & $\begin{array}{l}\text { Based on regression } \\
\text { of squared residuals }\end{array}$ & .0041599 & .949 \\
\hline
\end{tabular}

Table 5 represents the VAR Lag Order Selection Criteria based on Sequential modified LR Test Statistic, Final Prediction Error, Akaike Information Criterion, Schwarz Information Criterion and Hannan-Quinn information Criterion. Results showed variation in the lag structure based on different Criterion. However, SC (Schwarz Information Criterion), and $\mathrm{HQ}$ (Hanan-Quinn Information Criterion) represented that Lag 1 is appropriate lag Structure While AIC (Akaike Information Criterion) and FPE (Final prediction Error) represented that Lag 2 is appropriate Lag Structure. Sequential modified LR Test Statistic is showing larger variation in Lag Structure by showing Lag 5 as appropriate Lag Structure. In this study we have relied on the results of SC (Schwarz Information Criterion) and on HQ (Hannan-Quinn Information Criterion) and decided that Lag 1 is the appropriate Lag Structure. This study has analysed the data using Lag Structure 1 in all tests where appropriate Lag Structure was necessary to be identified.

\section{Table 6: VAR Lag Order Selection Criteria}

\begin{tabular}{ccccccc}
\hline \multicolumn{7}{c}{ Endogenous variables: KSE PI CPI IP ER EXPORT } \\
\multicolumn{7}{c}{ Exogenous variables: C } \\
\hline Lag & LogL & LR & FPE & AIC & SC & HQ \\
0 & 39.82915 & NA & $2.56 e-08$ & -0.454083 & -0.333118 & -0.404937 \\
1 & 1197.730 & 2207.006 & $7.38 \mathrm{e}-15$ & -15.51315 & $-14.66640^{*}$ & $-15.16913^{*}$ \\
2 & 1243.988 & 84.44402 & $6.45 \mathrm{e}-15^{*}$ & $-15.65084^{*}$ & -14.07831 & -15.01195 \\
3 & 1272.362 & 49.51251 & $7.18 \mathrm{e}-15$ & -15.54849 & -13.25017 & -14.61472 \\
4 & 1303.171 & 51.27822 & $7.78 \mathrm{e}-15$ & -15.47880 & -12.45469 & -14.25016 \\
5 & 1349.554 & $73.46620^{*}$ & $6.89 \mathrm{e}-15$ & -15.61817 & -11.86828 & -14.09465 \\
6 & 1373.736 & 36.35348 & $8.29 \mathrm{e}-15$ & -15.45954 & -10.98386 & -13.64114 \\
7 & 1401.517 & 39.52771 & $9.62 \mathrm{e}-15$ & -15.34922 & -10.14775 & -13.23595 \\
8 & 1433.807 & 43.34261 & $1.06 \mathrm{e}-14$ & -15.29942 & -9.372173 & -12.89128 \\
9 & 1458.998 & 31.78399 & $1.32 \mathrm{e}-14$ & -15.15433 & -8.501294 & -12.45131 \\
10 & 1488.269 & 34.57560 & $1.57 \mathrm{e}-14$ & -15.06401 & -7.685191 & -12.06612 \\
11 & 1526.094 & 41.63262 & $1.71 \mathrm{e}-14$ & -15.08851 & -6.983899 & -11.79574 \\
12 & 1568.386 & 43.14343 & $1.80 \mathrm{e}-14$ & -15.17296 & -6.342568 & -11.58532 \\
\hline
\end{tabular}

* indicates lag order selected by the criterion, LR: sequential modified LR test statistic (each test at $5 \%$ level), FPE: Final prediction error, AIC: Akaike information criterion, SC: Schwarz information criterion $H Q$ : Hannan-Quinn information criterion 


\subsection{Political Instability and Stock Market:}

This part of the study addressed the question of long and short relationship between stock market and political instability. Table 7, 8 and 9 represents the results of the impact of political instability in Pakistan on Karachi Stock Market in Short and Long Run. This Bi-Variate Relationship has been re-examined in the next Part with the inclusion of control variables. ARDL Co-integration for long run relationship has been used and results are reported in the Table 7 and 8 . Results of ARDL and its coefficients are reported. These results are reported based on the two variables first the Political Instability and second the Karachi Stock Market Index. In the next section same procedure has been repeated after inclusion of control variables. Results of these two tables report that political instability has significant negative relationship with stock market return in the long run. Unit Root Test for stationarity of data has given different level of integration for both variables which has made ARDL Co-integration appropriate test instead Jhonson and Julius Test.

\section{Table 7}

Autoregressive Distributed Lag Estimates

ARDL $(1,0)$ selected based on Schwarz Bayesian Criterion

\begin{tabular}{|c|c|c|}
\hline \multicolumn{3}{|l|}{ Dependent variable is $\mathrm{X} 1$} \\
\hline \multicolumn{2}{|c|}{179 observations used for estimation from } & 2 to 180 \\
\hline Regressor & Coefficient & Standard Error \\
\hline $\mathrm{X} 1(-1)$ & 1.0072 & $186.2770[.000]$ \\
\hline $\mathrm{X} 2$ & .0093509 & $-2.4677117[.027]$ \\
\hline R-Squared & .99001 & R-Bar-Squared \\
\hline S.E. of Regression & .095502 & F-stat. $F(1,177) \quad 17532.9[.000]$ \\
\hline Mean of Dependent Variable & 8.4782 & S.D. of Dependent Variable $\quad .95260$ \\
\hline Residual Sum of Squares & 1.6144 & Equation Log-likelihood \\
\hline Akaike Info. Criterion & 165.4163 & Schwarz Bayesian Criterion $\quad 162.2289$ \\
\hline DW-statistic & 1.9426 & Durbin's h-statistic \\
\hline
\end{tabular}

Where; X1 represents KSE (Karachi Stock Exchange), X2 represents PI (Political Instability), X3 represents CPI (Consumer Price Index), X4 represents IP (Industrial Production), X5 represents ER (Exchange Rate) and $\mathrm{X} 6$ represents Exports. 
Table 8

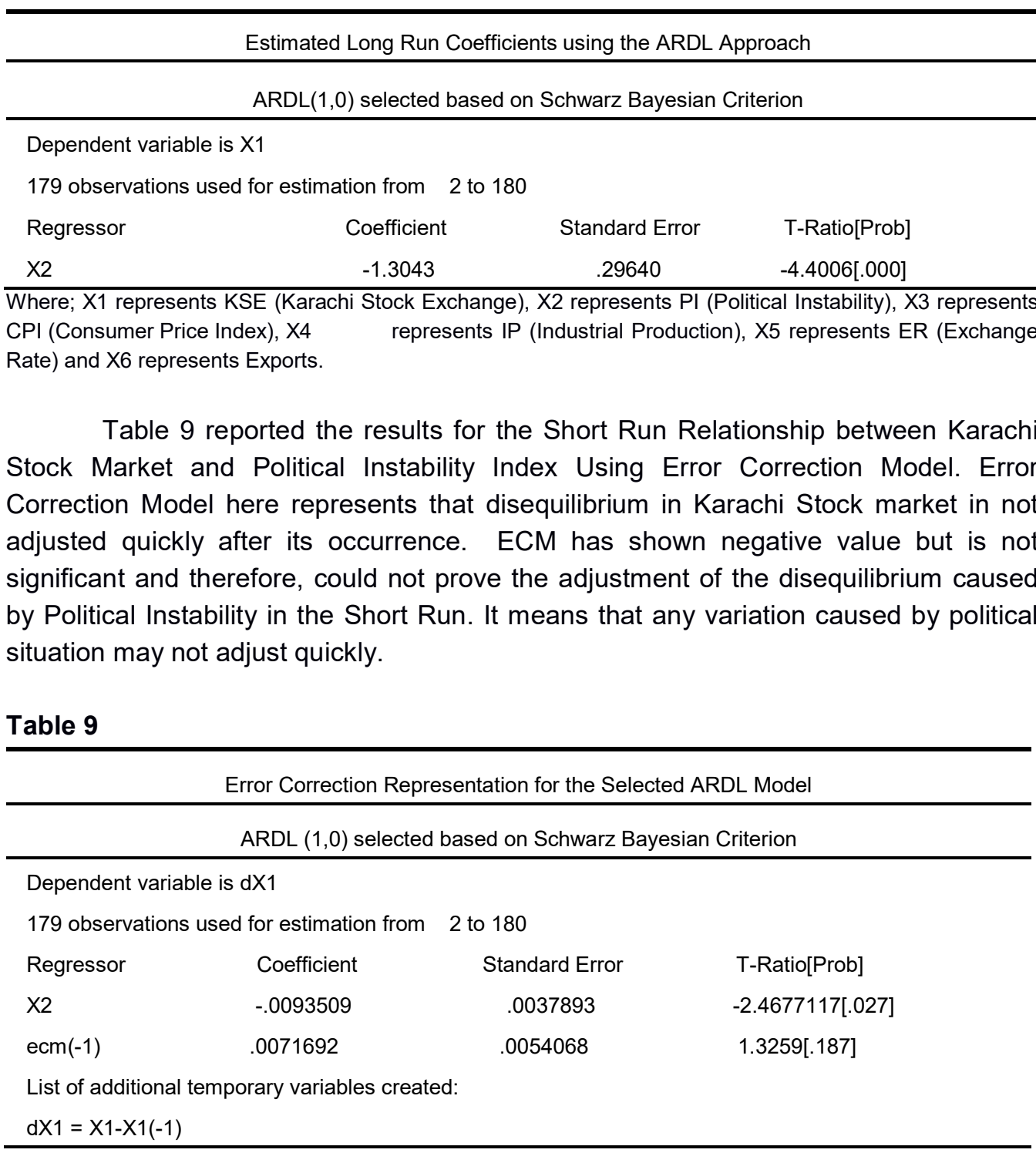

Where; X1 represents KSE (Karachi Stock Exchange), X2 represents PI (Political Instability), X3 represents CPI (Consumer Price Index), X4 represents IP (Industrial Production), X5 represents ER (Exchange Rate) and $\mathrm{X} 6$ represents Exports.

\subsection{Political Instability and Stock Market with Control Variables:}

Results of the ARDL model in case of bi-variate relationship between Stock market and political instability has shown that unstable political situation will adversely affect the stock prices in Pakistan. However, these results have been re-tested using Multivariate Relationship by inclusion of Control Variables in the Model to check the robustness of the results. Results have shown that this relationship has not changes 
after the inclusion of CPI, Industrial Production, Exchange Rate and Exports. These findings strengthen the practical implications of this study.

Table 10 represents the results of ARDL model for measurement of long run relationship among dependent and independent variables. ARDL co-integration is used when all the series are not integrated at same level. Results of Unit Root Test as reported in Table 4 showed that all the series are integrated at level 1 except Political Instability Index which was not integrated at levels and on level 1. Jhonson Julies CoIntegration Technique is used when all the series are stationary at same level and this situation directs the author to use ARDL model. Based on the difference in level of integration of series it was preferred in this study to use ARDL model. Results of the model explained that Political Instability, Industrial Production shows significant negative and Consumer Price Index have significant negative relationship with stock market index. However, Exchange Rate showed insignificant relationship with the stock market index. Exports showed positive relationship with Karachi Stock Market Index which shows that increase in Exports will ultimately bring positive change in stock prices.

Table 10: Autoregressive Distributed Lag Estimates

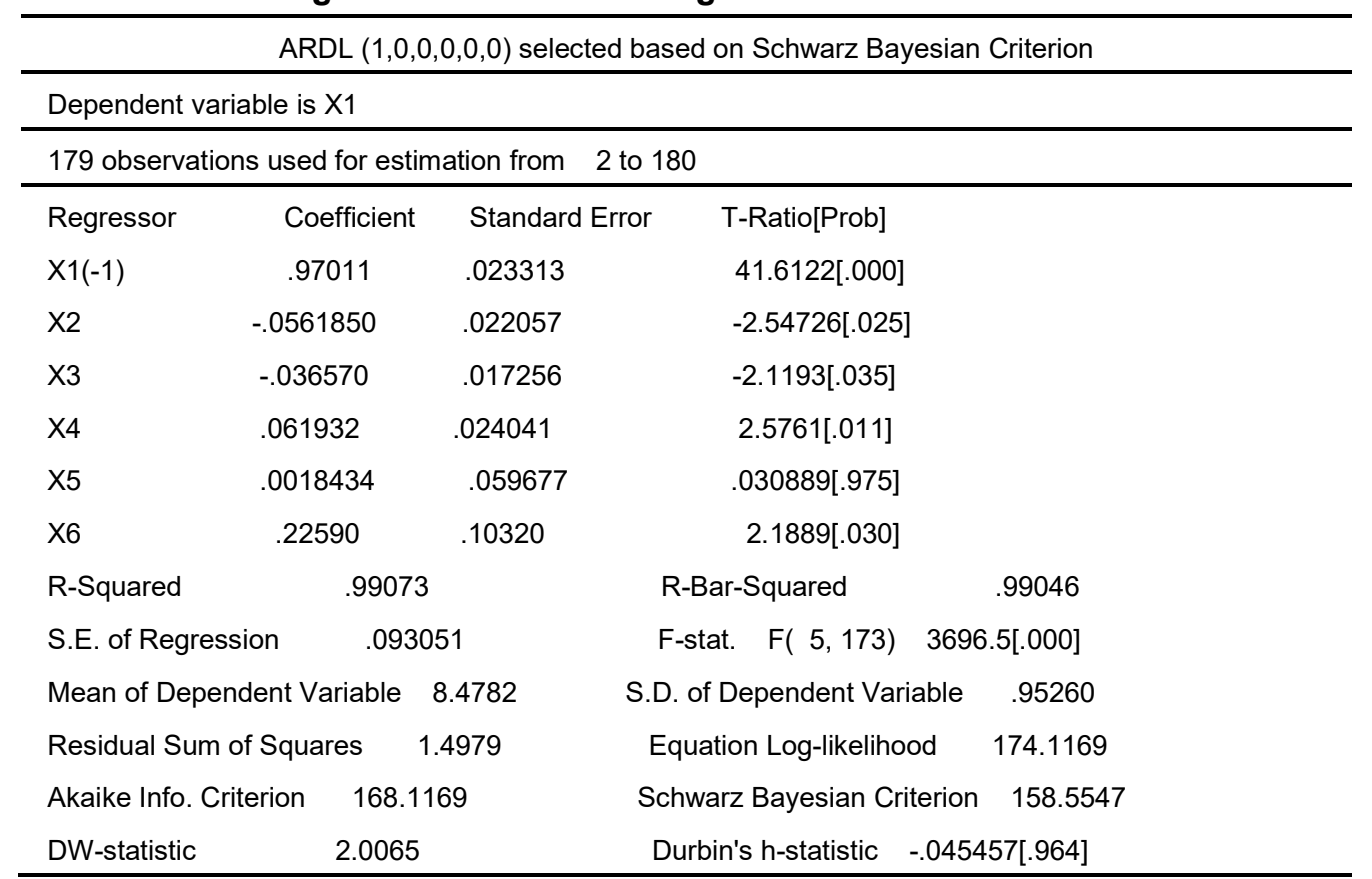

Where; X1 represents KSE (Karachi Stock Exchange), X2 represents PI (Political Instability), X3 represents CPI (Consumer Price Index), X4 represents IP (Industrial Production), X5 represents ER (Exchange Rate) and $\mathrm{X} 6$ represents Exports.

Table 11 represents the long run co-efficient using the ARDL approach. Results showed that industrial production do have significant negative relationship with stock prices. Exports do have significant positive relationship with stock prices. 
Industrial production showed positive relationship with stock prices at 10 percent level of significance. Long Run Co-efficient using ARDL approach showed insignificant relationship of stock price with Exchange Rate and Consumer Price Index.

Table 11

Estimated Long Run Coefficients using the ARDL Approach

ARDL $(1,0,0,0,0,0)$ selected based on Schwarz Bayesian Criterion

\begin{tabular}{|c|c|c|c|}
\hline \multicolumn{4}{|c|}{ Dependent variable is $\mathrm{X} 1$} \\
\hline \multicolumn{4}{|c|}{179 observations used for estimation from 2 to 180} \\
\hline Regressor & Coefficient & Standard Error & T-Ratio[Prob] \\
\hline $\mathrm{X} 2$ & -.28797 & .13353 & $-2.156594[.029]$ \\
\hline $\mathrm{X} 3$ & -1.2235 & 1.3177 & $-.92851[.354]$ \\
\hline $\mathrm{X} 4$ & 2.0720 & 1.1261 & $1.8400[.067]$ \\
\hline $\mathrm{x} 5$ & .061672 & 2.0119 & $.030653[.976]$ \\
\hline $\mathrm{x} 6$ & 7.5579 & 3.5140 & $2.1508[.033]$ \\
\hline
\end{tabular}

Where; X1 represents KSE (Karachi Stock Exchange), X2 represents PI (Political Instability), X3 represents CPI (Consumer Price Index), X4 represents IP (Industrial Production), X5 represents ER (Exchange Rate) and $X 6$ represents Exports.

Table 12 represented the results for the Error Correction Model. ARDL Cointegration is used to analyse the long run relationship while the ECM (Error Correction Model) is used to analyse the short run dynamics. Error Correction Model tells about the adjustment of disequilibrium in one variable due to the changes in its lagged values and due to changes in other variables. Results of the model explained that Political Instability and Consumer Price Index have significant negative relationship with stock market index. Industrial Production shows the positive relationship with the stock market in the short run. However, Exchange Rate showed insignificant relationship with the stock market index. Exports showed positive relationship with Karachi Stock Market Index which shows that increase in Exports will ultimately bring positive change in stock prices. Negative insignificant value of ECM suggests that adjustment process in KSE is not fast and disequilibrium process in Karachi Stock Market is not adjusted quickly in the short run. It shows that adjustment process is slow and prices are not adjusted quickly. Any change in stock prices due to the changes in political environment and other control variables is adjusted slowly in the stock prices. 
Table 12

\begin{tabular}{|c|c|c|}
\hline \multicolumn{3}{|c|}{ Error Correction Representation for the Selected ARDL Model } \\
\hline \multicolumn{3}{|c|}{ ARDL $(1,0,0,0,0,0)$ selected based on Schwarz Bayesian Criterion } \\
\hline \multicolumn{3}{|l|}{ Dependent variable is $\mathrm{dX} 1$} \\
\hline \multicolumn{3}{|c|}{179 observations used for estimation from 2 to 180} \\
\hline Coefficient & Standard Error & T-Ratio[Prob] \\
\hline-.0561850 & .022057 & $-2.54726[.025]$ \\
\hline-.036570 & .017256 & $-2.1193[.035]$ \\
\hline .061932 & .024041 & $2.5761[.011]$ \\
\hline .0018434 & .059677 & $.030889[.975]$ \\
\hline .22590 & 10320 & 2.1889[.030] \\
\hline-.029890 & .023313 & $-1.2821[.202]$ \\
\hline \multicolumn{3}{|c|}{ List of additional temporary variables created: } \\
\hline \multicolumn{3}{|c|}{$\mathrm{dX} 1=\mathrm{X} 1-\mathrm{X} 1(-1)$} \\
\hline \multicolumn{3}{|l|}{$\mathrm{dX} 2=\mathrm{X} 2-\mathrm{X} 2(-1)$} \\
\hline \multicolumn{3}{|l|}{$\mathrm{dX} 3=\mathrm{X} 3-\mathrm{X} 3(-1)$} \\
\hline \multicolumn{3}{|l|}{$\mathrm{dX} 4=\mathrm{X} 4-\mathrm{X} 4(-1)$} \\
\hline \multicolumn{3}{|l|}{$d \times 5=X 5-X 5(-1)$} \\
\hline \multicolumn{3}{|l|}{$d X 6=X 6-X 6(-1)$} \\
\hline \multicolumn{3}{|c|}{$\mathrm{ecm}=\mathrm{X} 1-.18797^{*} \mathrm{X} 2+1.2235^{*} \mathrm{X} 3+2.0720^{*} \mathrm{X} 4-.061672^{*} \mathrm{X} 5-7.5579^{*} \mathrm{X} 6$} \\
\hline R-Squared & R-Bar-Squared & .050091 \\
\hline S.E. of Regression & F-stat. $\quad F(5,173) \quad 2.87$ & $73[.016]$ \\
\hline Mean of Dependent Variable .013139 & S.D. of Dependent Variable & .095473 \\
\hline Residual Sum of Squares 1.4979 & Equation Log-likelihood & 174.1169 \\
\hline Akaike Info. Criterion $\quad 168.1169$ & Schwarz Bayesian Criterion & 158.5547 \\
\hline DW-statistic & & \\
\hline
\end{tabular}

R-Squared and R-Bar-Squared measures refer to the dependent variable $\mathrm{dX} 1$ and in cases where the error correction model is highly restricted, these measures could become negative.

Where; X1 represents KSE (Karachi Stock Exchange), X2 represents PI (Political Instability), X3 represents CPI (Consumer Price Index), X4 represents IP (Industrial Production), X5 represents $\quad$ ER (Exchange Rate) and $X 6$ represents Exports.

\subsection{Market Volatility}

Table 13: Heteroscedasticity Test: ARCH

\begin{tabular}{llll}
\hline F-statistic & 0.431019 & Prob. F(1,175) & 0.5124 \\
Obs*R-squared & 0.434873 & Prob. Chi-Square(1) & 0.5096 \\
\hline
\end{tabular}

In linear regression analysis, it is the assumption that variance of the standard error terms is constant and have mean zero. This is the basic assumption used in regression analysis and this is called homoscedasticity and in inverse case it is called heteroscedasticity. In this case error terms might be larger for some observations or periods of data than for others. To address such type of observations/data ARCH (Auto Regressive Conditional Heteroscedasticity) model was designed. This model is applied when data shows auto-correlation and Heteroscedasticity. Table 13 is used to check if data have both of these issues and if these issues exist then data is further 
analysed for the existence of volatility. Results showed that monthly data of KSE (Karachi Stock Market) is not suitable for applying ARCH methodology because ARCH Test represents that data do not have heteroscedasticity and auto correlation problems. However, this study has applied the next two results just for the purpose of reporting the complete information about data structure.

\section{Table 14}

\begin{tabular}{|c|c|c|c|c|}
\hline \multicolumn{5}{|c|}{$\begin{array}{c}\text { Dependent Variable: KSE } \\
\text { Method: ML - ARCH (Marquardt) - Normal distribution }\end{array}$} \\
\hline \multicolumn{5}{|c|}{$\mathrm{GARCH}=\mathrm{C}(3)+\mathrm{C}(4)^{\star} \mathrm{RESID}(-1)^{\wedge} 2$} \\
\hline Variable & Coefficient & Std. Error & z-Statistic & Prob. \\
\hline C & 0.013143 & 0.008428 & 1.559542 & 0.1189 \\
\hline \multirow[t]{2}{*}{ KSE(-1) } & 0.032811 & 0.092571 & 0.354438 & 0.723 \\
\hline & Variance Equation & & & \\
\hline C & 0.00864 & 0.000609 & 14.18536 & 0 \\
\hline $\operatorname{RESID}(-1)^{\wedge} 2$ & 0.048139 & 0.080718 & 0.59639 & 0.5509 \\
\hline R-squared & 0.001757 & Mean depend & nt var & 0.012965 \\
\hline Adjusted R-squared & -0.00392 & S.D. depende & t var & 0.095713 \\
\hline S.E. of regression & 0.0959 & Akaike info cr & erion & -1.82344 \\
\hline Sum squared resid & 1.618653 & Schwarz crite & & -1.75194 \\
\hline Log likelihood & 166.2858 & Hannan-Quin & criter. & -1.79444 \\
\hline Durbin-Watson stat & 1.96945 & & & \\
\hline
\end{tabular}

Table 14 and Table 15 are given to include the complete detail of all the issue which was important regarding the stock prices in Karachi Stock Market. These tables' reports that lagged monthly returns of KSE (Karachi Stock Market) are not able to predict its current returns. Insignificant values of KSE $(-1)$ and insignificant value of RESID (-1) ^2 showed that past returns are not appropriate to predict the current returns volatility. ARCH model is also applied by including control variables and results were similar in that stock market volatility is not explained by its own lagged terms and by the political instability and other control variables like CPI, Industrial production, Exchange Rate and Exports. 
Table 15: Dependent Variable: KSE, Method: ML - ARCH (Marquardt) - Normal distribution

\begin{tabular}{|c|c|c|c|c|}
\hline \multicolumn{5}{|c|}{$\mathrm{GARCH}=\mathrm{C}(8)+\mathrm{C}(9)^{\star} \mathrm{RESID}(-1)^{\wedge} 2+\mathrm{C}(10)^{\star} \mathrm{GARCH}(-1)$} \\
\hline Variable & Coefficient & Std. Error & z-Statistic & Prob. \\
\hline C & 0.019483 & 0.007865 & 2.477164 & 0.0132 \\
\hline $\operatorname{KSE}(-1)$ & 0.102893 & 0.062458 & 1.647388 & 0.0995 \\
\hline $\mathrm{PI}$ & 0.029287 & 0.027702 & 1.057196 & 0.2904 \\
\hline CPI & -0.04635 & 0.053515 & -0.86606 & 0.3865 \\
\hline EXPORT & 0.149324 & 0.109591 & 1.362548 & 0.173 \\
\hline IP & 0.14912 & 0.152375 & 0.97865 & 0.3278 \\
\hline ER & -1.49002 & 0.53254 & -2.79795 & 0.0051 \\
\hline \multicolumn{5}{|l|}{ Variance Equation } \\
\hline C & 0.000304 & 0.000101 & 2.997978 & 0.0027 \\
\hline $\operatorname{RESID}(-1)^{\wedge} 2$ & -0.01806 & 0.00705 & -2.56141 & 0.0104 \\
\hline GARCH(-1) & 0.965574 & 0.0129 & 74.85285 & 0 \\
\hline R-squared & 0.046413 & \multicolumn{2}{|c|}{ Mean dependent var } & 0.012965 \\
\hline Adjusted R-squared & 0.012954 & \multicolumn{2}{|c|}{ S.D. dependent var } & 0.095713 \\
\hline S.E. of regression & 0.095091 & \multicolumn{2}{|c|}{ Akaike info criterion } & -1.96299 \\
\hline Sum squared resid & 1.546242 & \multicolumn{2}{|c|}{ Schwarz criterion } & -1.78424 \\
\hline Log likelihood & 184.7058 & \multicolumn{2}{|c|}{ Hannan-Quinn criter. } & -1.8905 \\
\hline Durbin-Watson stat & 2.149178 & & & \\
\hline
\end{tabular}

\section{Conclusion}

Political instability was measured by different factors like strikes, assassinations, riots, demonstrations, government longevity, government change and regime Type. The control of government over strikes, assassinations, riots and demonstrations will stabilize the political situation and stable political situation will create better investment environment. Political stability reduces the uncertainty and urges investors to put their funds in different investments. Political stable governments will have an approach to facilitate the investors.

The main focus of this study was on the relationship between stock prices and political instability. Results showed negative relationship between these two variables. Governments should try to reduce the events which increase instability in political situation. Results of this study showed the positive relationship of industrial production with the stock prices. Governments need to put special attention towards the level of industrial production in the country. 
Moreover, energy crises are one of the major barriers in the way of industrial production. Governments should try to resolve issue of energy crises because energy crises affect industrial production and industrial production ultimately leads towards better performance of stock market. Inflation has shown negative relationship with stock prices. ARDL Co-integration results shows that exports have positive relationship with stock prices like the relationship of industrial production and stock prices. Government should make policies in order to support the corporations to increase the level of exports to other countries. The measures of government to increase the level of exports have positive effect on the stock market. Inflation has shown negative relationship with stock prices. Increase in inflation raises the level of interest rates in the economy. Interest rates do have negative relationship with the stock market. Governments should try to control the general level of prices in the country in order to control the inflationary pressure on the economy. Increase in interest rates will raise the required rate of return on the investments and ultimately it will decrease the stock prices.

\section{Future Research Directions}

Further studies should be conducted to increase more components in the construction of political instability index like suicide attacks in the country, wars drone attacks. This study has considered strikes, assassinations, riots, demonstrations, government longevity, government change and regime type as factors for constructing the political instability index. However, factors like drone attacks, suicide attacks are important factor making the political situation unstable and therefore, further research should be conducted by taking enough data on these factors and to include them in construction of political instability index. Further, studies should be conducted by increasing the sample period. Relationship of stock prices and political instability was examined using four control variables (Inflation, Industrial Production, Exchange Rate and Exports) in this study. However, a more detailed analysis could be conducted by including other control variables like legal systems, foreign investments and energy crises.

\section{References}

Alesina A., Ozler S., Roubini N. Swagel P. (1992) "Political Instability and Economic Growth" (September), NBER Working Paper \# 4173.

Alesina A., Roubini N., Cohen G., (1993) "Electoral business cycle in industrial democracies",

Almeida H., Ferreira D. (2002) "Democracy and the variability of economic performance: Domestic and international sources of economic activity", Economics and Politics 14, 225-257.

Alt J., Chrystal K., (1983) Political Economics (University of California Press: Berkeley, CA.).

Ali, Haji Suleman, Shujahat Haider Hashmi, and Arshad Hassan. "Relationship Between Political Instability and Domestic Private Investment in Pakistan: A Time Series Analysis (19722009)." Pakistan Business Review (2013) (2013). 
Anthony A., (2000) "Social Fractionalization, Political instability and the size of Government", IMF Working Paper, WP/00/82.

Barro R. J., Lee J., (1994) "Sources of Economic Growth", Carnegie Rochester Conference Series on Public Policy.

Bashir M., F., Xu C., Zaman K., Akhmat. G., Ikram M., (2013), "Impact of foreign political instability on Chinese exports", Economic Modeling 33 (2013) 802-807

Beaulieu M. C, Cosset J. C and Essaddam N. (2005)" The impact of political risk on the volatility of stock returns: the case of Canada" Journal of International Business Studies 36, 701-718

Ben-Habib J., Spiegel M., (1992) "The Role of Human Capital and Political Instability in Economic Development." Economic Research Report. New York University, C. V. Starr Center for Applied Economics, New York. Processed.

Bernhard W., Leblang D., (2006) "Democratic Processes and Financial Markets: Pricing Politics" (Cambridge University Press: Cambridge, U.K.).

Berthelemy J.C., Kauffmann C., Renard L.Wegner L., (2002) "Political Instability, Political Regimes and Economic Performance in African Countries" African Economic Outlook (March).

Between Political Instability and Economic Growth in Nepal (1975-2003)" South Asia Network

Bittlingmayer G., (1998) "Output, stock volatility, and political uncertainty in a natural experiment: Germany 1880-1940", Journal of Finance 53, 2243-2256.

Blake L., "Some Relations between Volatility and Serial Correlation in Stock Market Returns", Journal of Business, LXV 1992, 199-219.

Botero J., Djankov S., La Porta R., Lopez-de-Silanes F., (2004) "The regulation of labor", Quarterly Journal of Economics 119, 1339-1382.

Boutchkove. M., Doshi H., Durnev A., (2010), "Precarious Politics and Return Volatility", The Review of Financial Studies, Volume 25.

Brempong Traynor (1999) "Political Instability, Investment and Economic Growth in Sub-Saharan Africa, Journal of African Economies.

Bussie. M., and Mulder. C., (2000) "Political Instability and Economic Vulnerability", International Journal of Finance and Economic. 5: 309-330 (2000)

Bussiere M., Mulder C., (1999) "Political instability and economic vulnerability", International Monetary Fund Working Paper (WP/99/46).

Campos N. F., Karanasos M. G., (2008) "Growth, volatility and political instability: Nonlinear time-series evidence for Argentina, 1896-2000” Economics Letters, 100, pp.135-137.

Campos N. F., Nugent J. B., (1999) "Who is Afraid of Political Instability" University of Southern California, Mimeo.

Camposw N., F., Nugent J., B., (2002) Aggregate Investment and Political Instability an Econometric investigation, Economica (2003) 70, 533-549

Chan Y., Wei, J., (1996) "Political Risk and Stock Price Volatility: The Case of Hong Kong", Pacific Basin Finance Journal, vol. 4, 259-275

Clark, E., (1997), "Valuing Political Risk", Journal of International Money and Finance, 16, No. 3, 477-490.

Clark. E., Masood O., Tunaru R., (2006). "Political Events Affecting the Pakistan Stock Exchange: An Analysis of the Past and Forecasting the Future" presented QQASS, Special issue conference

Cosset J.C., Suret J.M., (1995) "Political Risk and the Benefits of International Portfolio Diversification", Journal of International Business Studies, 26, 2nd quarter, 301-318. 
Cutler, D., Poterba J., Summers L., (1989), 'What Moves Stock Prices?',Journal of Portfolio Management, 15, 4-11.

De Haan J., Siermann C., (1996), "Political Instability, Freedom and Economic Growth" Economic Development and Cultural Change, 44 339-50

Dimitrious A., Simon P., (2001) "Political Instability and Economic Growth: UK Time Series Evidence", Scottish Journal of Political Economy (September), Vol.48, No.4, pp.244249.

Dimitrious A., Siriopoulos C., (2000) "The Role of Political Instability in Stock Market Development and Economic Growth: The Case of Greece", Economic Notes, vol. 29(3), pp. 355-74

Durnev A., (2010) "The Real Effects of Political Uncertainty: Elections and Investment

Erb C.B., Harvey C.R., Viskanta T.E., (1996), "Political Risk, Economic Risk and Financial Risk”, Financial Analysts Journal, November-December.

European Journal of Political Economy 9, 1-23.

Examining American and British stock returns, 1930-2000", American Journal of Political Science 49, 780-802.

Foerster S., Schmitz J., (1997) "The transmission of U.S. election cycles to international stock returns", Journal of International Business Studies 28, 1-13.

Fosu A. K., (2001) "Political instability and economic growth in developing economies: some specification empirics", Economics Letters, 70, pp. 289-294.

Ghura D., Mercereau B., (2004) "Political Instability and Growth: The Central African

Greenwood J., Smith B., (1996) "Financial Markets in Development and Development in Financial Markets", Journal of Economics Dynamic and Control,21: 145-81

Growth", Journal of African Economies, Vol.8, No.1, pp.87-107.

Guillaumont P., Jeanneney, S.G., and Brun J.F., (1999) "How Instability Lowers African

Gul S., Khan M. T., Saif N., Rehman S., Roohullah (2013) "Stock Market Reaction to Political Events (Evidence from Pakistan)", Journal of Economics and Sustainable Development, Vol.4, No.1, 2013

Haber S., Raz A., Maurer N., (2000) "Political Instability, Credible Commitments and Economic Growth: Evidence from Revolutionary Mexico", Stanford University.

Hibbs D., (1977), Political parties and macroeconomic policy, American Political Science Review, 71, 1467-1487.

Hussain F., Qasim M. A., (1997) "The Pakistani Equity Market in 50 Years: A Review”, The Pakistan Development Review, 36:4 Part II (Winter 1997) pp. 863-872

Institute of Integrated Development Studies, Katmandu, Nepal (2005) “The Relationship

Khan, Shahrukh. "The military and economic development in Pakistan." Political Economy Research Institute, University of Massachusetts working paper series 291 (2012).

Khan A., Ahmed M. S., (2009), Trading Volume and Stock Return: The Impact of Events in Pakistan on KSE 100 Indexes", International Review of Business Research Papers Vol. 5 No. 5 September 2009 Pp. 373-383

Khan S.U., Saqib O.F., (2010), "Political instability and inflation in Pakistan" Journal of Asian Economics (8 September 2011)

Kim H.Y., and Mei J.P., (2001) "What makes the stock market jump? An analysis of political risk on Hong Kong stock returns", Journal of International Money and Finance 20: 10031016.

Klibanoff P., Lamont O., Wizman, T., 1998, "Investor reaction to salient news in closed-end country funds", Journal of Finance, 53 (2), 673-99. 
Knight B., (2006), "Are policy platforms capitalized into equity prices? Evidence from the Bush/Gore 2000 presidential election", Journal of Public Economics 90, 751-773.

Leblang D., Mukherjee B., (2005), "Government partisanship, elections, and the stock market:

Liu T., (2010), "Institutional Investor Protection and Political Uncertainty: Evidence from Cycles of Investment and Elections" Thesis Presented in Partial Fulfillment of the Requirements for the Degree of Master of Science in Administration (FINANCE) at John Molson School of Business Concordia University Montreal, Quebec, Canada

Malik. S., Hussain. S., and Ahmed. S., (2009) "Impact of Political Event on Trading volume and Stock Returns: The Case of KSE", International Review of Business Research Papers, Vol. 5 No. 4 June 2009 Pp. 354-364

Mckenzie M., Faff D., Robert W., (2003), "The Determinants of Conditional Autocorrelation in Stock Returns", The Journal of Financial Research, 26, 259- 274.

McMillian D., Speight A., (2002), "Return-volume dynamics in UK futures", Applied financial economics, 12, 707-713.

Mei J., Guo L., (2004), "Political uncertainty, financial crisis and market volatility", European Financial Management 10, 639-657.

Mitchell M., L., Mulhern J. H., (1994), "The impact of public information on the stock market", Journal of Business, 49, 496-508.

Niederhofer, Gibbs V. S., Bullock J., (1970). "Presidential Elections and the Stock Market" Financial Analysts Journal, 26: 111-113.

Ouattara B. (2005) "Modeling the Long Run Determinants of Private Investment in Senegal", Credit Research Paper, Centre for Research in Economic Development and International Trade, University of Nottingham

Pesaran M.H, Shin Y. AND Smith R.J (2001), "Bounds Testing Approaches to the Analysis of Level Relationships" Journal of Applied Econometrics, Journal of Applied Economics, 16: $289-326(2001$

Pesaran MH, Shin Y. (1999) "An autoregressive distributed lag modelling approach to cointegration analysis. Chapter 11 in Econometrics and Economic Theory in the 20th Century: The Ragnar Frisch Centennial Symposium ", Cambridge University Press: Cambridge

Przeworski A., Alvarez M., Michael A., Chiebub J., Limongi F., (2000) "Democracy and Developmen", (New York: Cambridge University Press, N.Y.)

Pyun C., Lee S., Nam K., (2000), "Volatility and information flows in emerging equity markets: A case of the Korean stock exchange", International Review of Financial Analysis, Vol. 9, pp. 405-420.

Qureshi M. N., Ali. K.., Khan I. R., (2010), "Political Instability and Economic Development:Pakistan Time-Series Analysis", International Research Journal of Finance and Economics, Issue 56 , 1450-2887

Ragunathan V., and Peker A., (1997), "Price variability, trading volume and market depth: evidence from the Australian futures market”, Applied Financial Economics, Vol. 7, pp. 447-4454.

Razi and Shakir (2005) "Pakistan 58 years- 14 August 1947 to 14 August 2005", Sang-e-Meel

Republic" IMF Working Paper/04/80, African and Asia and Pacific Department.

Santa-Clara, P., and Valkanov R. (2003), "The presidential puzzle: Political cycles and the stock market”, Journal of Finance 58, 1841-1872.

Sensitivity to Stock Prices," working paper, McGill University, September 2010

Snowberg. E., Wolfers J., Zitzewitz E.,( 2007), "Partisan impacts on the economy: Evidence from markets and close elections", Quarterly Journal of Economics 122, 807-829. 
Stickel S., Verrecchia R., (1994) "Evidence that Volume Sustains Price Changes", Financial Analysts Journal (November-December), 57-67.

Tang C., F., Abosedra S., (2013) "The impacts of tourism, energy consumption and political instability on economic growth in the MENA countries" (6 January 2014) Published by Elsevier Ltd.

Tauchen G. E., Pitts M., (1983), "The Price Variability Volume Relationship on Speculative Markets”, Econometrica, Vol.51, pp. 485- 505.

Telatar E., Telatar F., Cavusoglu T., Tosun, U., (2010) "Political instability, political freedom and inflation", Applied Economics, 2010, 42, 3839-3847

Voth H. J., (2002), "Stock price volatility and political uncertainty: Evidence from interwar period", working paper, Universitat Pompeu Fabra.

Wang J., (1994), "A model of competitive trading volume", Journal of Political Economy, Vol.102, pp. 127-168.

William E., Rebelo. S., (1993) "Fiscal Policy and Growth: An Empirical Investigation" Journal of Monetary Economics, 32, (December), pp.417-58.

Wolfers J., Zitzewitz E., (2009), "Using markets to inform policy: The case of the Iraq war", Economica 76, 225-250

Yi F., (1997) "Democracy, Political Instability and Economic Growth", British Journal of Political Science, Vol.27, No.3, pp.391-418.

Zureiqat H. M. (2005), "Political Instability and Economic Performance: A Panel Data 